\title{
Complete rations containing coarsely chopped or ground hay for dairy cows in confinement vs. conventional grazing'
}

\author{
Paul F. Randel
}

\begin{abstract}
Treatments $A$ and $B$, based on complete rations, and a conventional control (C) were compared in a completely randomized design including 8 preliminary days and 3 successive 28-day comparison periods with 17 cows (13 Holstein and 4 Brown Swiss). Both complete rations incorporated $60 \%$ basal concentrates, principally ground maize, soybean meal, wheat middlings and cane molasses, and $40 \%$ grass hay, but differed in the coarsely chopped hay in A and ground hay ( $9.5 \mathrm{~mm}$ screen) in B. Formulation specified $13 \%$ crude protein and $1.58 \mathrm{Mcal}$ of net energy for lactation/ $\mathrm{kg}$ of dry matter (DM). Each was fed to two groups of three cows, ad libitum in period 1 and restricted in periods 2 and 3 in late afternoon. During the hottest hours these animals rested under shade, which reduced thermal stress. Five control cows grazed rotationally at 2.5 animals/ha in gramineous swards of good quality, with individual supplementation of basal concentrates according to milk yield. Late in period I, DM intake (DMI) of A and B reached maxima of 22 and $23 \mathrm{~kg}$ per per. Mean results for $A, B$ and $C$, respectively, during 84 days were: daily DMI, 16.2, 16.4 and $6.0 \mathrm{~kg}$ (excluding pasture herbage), and as a percentage liveweight (IW), $2.96,2.98$ and 1.09 ; IW, 548,552 and $550 \mathrm{~kg}$; daily milk yield, $17.7,16.5$ and $16.0 \mathrm{~kg} ; 4 \%$ fat corrected milk (FCM), $15.0,13.7$ and 14.0 kg; milk fat percentage, 3.00, 2.87 and 3.19; FCM/concentrates DMI ratio, $1.55,1.39$ and 2.34. One cow of B died of acute bloat in period 2, possibly because of insufficiency of effective fiber in the rumen. Complete ration $A$ appears promising as a possible alternative for intensified dairying in Puerto Rico.
\end{abstract}

\section{RESUMEN}

Raciones completas con heno picado toscamente o molido para vacas lecheras estabuladas y pastadas convencionalmente

Se usaron 17 vacas ( 13 Holstein y 4 Pardas Suizas) en un experimento de diseño completamente aleatorio que incluyó 8 días preliminares y 3 períodos de estudio de $\mathbf{2 8}$ dias para comparar tratamientos A y B, basados en raciones completas, $y$ un $C$ (testigo). Las dos raciones completas incluyeron $60 \%$ de concentrados básico (mayormente maíz molido, harina de soya, salvado de trigo y melaza de caña) y $\mathbf{4 0} \%$ de heno de gramíneas, pero difirieron en que la A contó con heno picado y la B heno molido (zaranda de $9.5 \mathrm{~mm}$.). Téricamente ambas raciones contenían $13 \%$ de proteína bruta y $1.58 \mathrm{Mcal}$ de energía neta para lactación/kg. de materia

'Manuscript submitted to Editorial Board 8 November 1990.

${ }^{2}$ Animal Nutritionist, Department of Animal Science. The author gratefully acknowledges the contribution of the late Santos Noel Caraballo to this experiment. 
seca. Cada ración se le suplió a los 2 grupos de 3 vacas, a libre albedrío en el período 1 y en cantidades restringidas en los períodos 2 y 3 para consumo vespertino. Se les permitió descansar a la sombra durante las horas más calurosas para menguar la tensión térmica. Cinco vacas testigo apacentaron rotacionalmente forraje de buena calidad a razón de $\mathbf{2 . 5}$ animales/ha. y recibieron suplementación individual con los concentrados básicos, según su nivel productivo. Hacia fines del período I la ingestión de materia seca (DMI) de $A$ y $B$ alcanzaron niveles máximos de 22 y 23 kg. diarios. Los resultados medios en A, B y C durante 84 días fueron: DMI diario, 16.2, 16.4 y 6.0 (excluyendo el forraje pastado); DMI diario como porcentaje del peso vivo, 2.96, 2.98 y 1.09 ; peso vivo, 548,552 y $550 \mathrm{~kg}$.; producción diaria de leche, $17.7,16.5$ y $16.0 \mathrm{~kg}$. y de leche corregida a $4 \%$ grasa (FCM), $15.0,13.7$ y $14.0 \mathrm{~kg}$; porcentaje de grasa láctea, 3.00 2.87 y 3.19 ; razón FCM/DMI de concentrados $1.55,1.39$ y 2.34 . Una vaca B muría de timpanismo agudo en el período 2, posiblemente por falta de suficiente fibra efectiva en el rumen. La ración completa A muestra ser una posible alternativa para la granadería lechera intensiva en Puerto Rico.

\section{INTRODUCTION}

Traditional feeding practices with dairy cattle in Puerto Rico have been based on grazing or, to a lesser degree, green chopped forage and supplementation with commercial concentrate feeds. These methods are still applicable to a portion of the local farms, but many dairy operations have limitations that preclude primary reliance on pasture. The land area available for dedication to pasture and other forages has been diminishing in the principal milk producing regions because of urbanization and expansion of the non-agricultural sector of the economy. Thus, there is a growing need for alternative, more intensive systems of dairy management, especially where large herds are maintained in rather small land areas.

One such alternative, which has been widely and successfully adapted in other countries, is feeding of complete rations, i.e. single mixtures including both roughage and concentrates, to cows in confinement or semi-confinement (2). Extensive research conducted in Puerto Rico during the late 1960s and early 1970s demonstrated the feasibility of feeding complete rations with ground sugarcane bagasse as roughage (7). Use of complete rations and confinement of animals greatly increases milk production per unit of land employed in dairying operations and permits optimal use of least-cost ration formulation. Feed efficiency may be improved because of exact control of the roughage/concentrate ratio and other dietary characteristics. At present, gramineous hay is the principal harvested forage available and is thus the logical choice for a fibrous material on which to base complete rations.

The experiment reported herein is the first of a series undertaken to evaluate this type of complete ration. The objective was to compare two complete rations with $40 \%$ grass hay, either coarsely chopped or ground to medium fineness, and $60 \%$ concentrate ingredients. A control treat- 
ment of a conventional type based on grazing and concentrate supplementation was also included.

\section{MATERIALS AND METHODS}

The 17 cows of the Lajas Substation herd used in this experiment included 13 Holstein and 4 Brown Swiss, 4,3 and 10 of which were in 1st, 2nd and 3rd or later lactation, respectively. Neither breed nor lactation number was considered in assigning the cows to treatment groups, but the groups were balanced as uniformly as possible in initial milk yield and stage of lactation. The latter ranged initially from 1 to 24 weeks post-partum. The experiment, which lasted 92 days, included an 8-day preliminary period and 3 successive 28-day comparison periods; it employed a complete randomized design to compare three different rations.

Treatments $\mathrm{A}$ and $\mathrm{B}$ involved management in total confinement and feeding 2 complete rations differing only in physical form of the roughage. The formula common to both complete rations (table 1) included $60 \%$ of a mixture of concentrate ingredients (designated basal concentrates) and $40 \%$ of gramineous hay, and was calculated to contain $13 \%$ of crude protein (CP) and approximately $1.58 \mathrm{Mcal}$ of net energy for lactation (NEL)/ $\mathrm{kg}$ of dry matter (DM). Tabular values of the National Research Counci] (NRC) (6) were used for the concentrate ingredients, but since hay of local grass species does not appear in these tables, digestibility data for local hays of similar type and practical experience were relied on to derive estimates of $5 \% \mathrm{CP}$ and $1.2 \mathrm{Mcal} \mathrm{NEL} / \mathrm{kg}$ DM for the hay. Because of short supplies, it was necessary to use hay from several different lots,

TABLE 1. Formulas of complete rations and basal concentrates and theoretical nutrient contents on dry matter basis

\begin{tabular}{|c|c|c|}
\hline Ingredient & $\begin{array}{l}\text { Complete } \\
\text { rations }\end{array}$ & $\begin{array}{c}\text { Basal } \\
\text { concentrates }\end{array}$ \\
\hline Ground yellow maize & 27.46 & 45.77 \\
\hline Soybean meal & 12.52 & 20.87 \\
\hline Wheat middlings & 11.77 & 19.62 \\
\hline Cane molasses & 6.00 & 10.00 \\
\hline Salt & 1.00 & 1.67 \\
\hline Urea & 0.50 & 0.83 \\
\hline Ground limestone & 0.50 & 0.83 \\
\hline Dicalcium phosphate & 0.25 & 0.41 \\
\hline Grass hay' & 40.00 & -- \\
\hline Crude protein & 13.0 & 18.3 \\
\hline Net energy for lactation (Mcal/kg) & 1.58 & 1.83 \\
\hline
\end{tabular}

'Coarsely chopped in treatment A and ground through a $9.5 \mathrm{~mm}$ screen in treatment $B$. 
of varying stages of maturity, during the course of the experiment. Complete rations $\mathrm{A}$ and $\mathrm{B}$ contained either hay coarsely chopped in a forage harvester or hammer milled through a $9.5 \mathrm{~mm}$ screen, respectively.

The 12 cows assigned to treatments A and B were separated daily after p.m. milking into four equal groups and confined to four pens, which were paved and equipped with a feed bunk and automatic watering cup; one was located under a sheet metal roof and the other three under saran shade. The group in each pen had access to its respective complete ration (A in pens 2 and 3, B in $\mathrm{l}$ and 4 ) until a.m. milking of the following day. During the preliminary period daily offerings were limited to $50 \mathrm{~kg}$ of complete ration in pens 2,3 and 4 , and $65 \mathrm{~kg}$ in pen 1 , where feed was consumed very aggressively. During comparison period 1 , frequent adjustments were made in the daily offering in an attempt to determine maximum voluntary intake without excessive feed refusals; during periods 2 and 3 , daily feed allowances were limited to fixed amounts deemed reasonably proportional to milk yield. The cows spent the hottest hours of the day, between a.m. and p.m. milkings, in an unpaved rest area in which adequate shade was provided by trees; drinking water, but not feed, was available.

The 5 cows assigned to treatment $\mathrm{C}$ received the same basal concentrates previously mentioned (table 1 ) as a supplement to grazing. This mixture, calculated to supply $18.3 \% \mathrm{CP}$ and $1.83 \mathrm{Mcal}$ NEL/kg DM, was fed individually to the cows stanchioned in a shade barn during late morning hours. The rate of supplementation was $8 \mathrm{~kg}$ per head during the preliminary period; thereafter, a daily assignment equal to $1 \mathrm{~kg}$ per $2 \mathrm{~kg}$ of milk produced in excess of $5 \mathrm{~kg}$ was calculated at the start of comparison periods 1 and 2 . The daily assignments were not recalculated upon beginning period 3 in order to avoid a too rapid decline in milk production. Control cows spent the remaining hours during the interval between the 2 daily milkings in an unpaved enclosure with drinking water available and where some shade was provided by shadows of adjacent buildings, but the shaded area was less than optimal to accommodate 5 animals. After p.m. milking these cows grazed swards of heterogenous gramineous herbage, in 0.5 ha paddocks, at a stocking rate of 2.5 animals/ ha. Twelve contiguous paddocks were used in a 24-day cycle, with rotation of paddock every other day. Non-experimental cows were added to maintain the desired stocking rate. Throughout 92 days of experimentation, from March to June 1988 the swards were judged to be very good, i.e., assigned to a value of 6 on a subjective scale from 0 to 8 considering both quantity and quality of herbage. This was the result of a good distribution of a total of $239 \mathrm{~mm}$ of rain that fell during the said period.

The experimental animals were weighed after a.m. milking on one day at the conclusion of each of the 4 periods. Individual milk samples from two consecutive milkings were also taken during the latter part of 
each period, and combined into a single sample per cow for analysis of fat content by the Badcock procedure (1). Samples of the complete rations and of the basal concentrates were accumulated by frequent additions during each of the three comparison periods for subsequent oven drying at $80^{\circ} \mathrm{C}$ to determine $\mathrm{DM}$ content.

The data from the comparison phase of the experiment were subjected to a one factor analysis of variance (8), in which pens in A and B and individual cows in $\mathrm{C}$ represented the treatment replications. Therefore, there were eight total degrees of freedom: two for treatments and six for error.

\section{RESULTS AND DISCUSSION}

During the preliminary period the complete rations were consumed at maximum levels, as evidenced by feed refusals left in the feed bunks, on about 4 of the 8 days by cows of groups 2,3 , and 4 , whereas no feed was refused by group 1 . Consumption of the complete rations continued its upward trend for at least the first 3 weeks of comparison, until maximum intakes for a single day of $75 \mathrm{~kg}$ (groups 2 and 3) and $80 \mathrm{~kg}$ (groups 1 and 4 ) were recorded late in period 1 . These figures correspond to intake per head of 25.0 and $26.7 \mathrm{~kg}$ for $\mathrm{A}$ and $\mathrm{B}$, equivalent to DM intakes in excess of 22 and $23 \mathrm{~kg}$, respectively. These extraordinary ingestive levels point to the utility of this type of feeding system for coping with the elevated nutrient requirement of high-yielding cows in early lactation. Over 28 days of period 1 , mean DM intakes for $A$ and $B$ were 18.0 and $18.7 \mathrm{~kg}$ daily (table 2), which represent a bit less than might have been consumed if completely ad libitum conditions had prevailed everyday of the period. According to NRC tables (5), cows similar to those of the present study, weighing $550 \mathrm{~kg}$, producing $15 \mathrm{~kg}$ of $4 \%$ fat-corrected milk (FCM) and gaining .5 kg of liveweight (LW) daily, are predicted to consume $17.9 \mathrm{~kg}$ of DM of a ration containing $2.85 \mathrm{Mcal}$ $\mathrm{DE}^{3} / \mathrm{kg}$, which agrees well with observations in $\mathrm{A}$ and $\mathrm{B}$. The physical form of these rations, particularly $B$, may have allowed a rather fast rate of passage. If this is true, some degree of digestibility depression would be expected, with less than the theoretical amount of energy actually available to the animals.

Feed refusals were very infrequent during periods 2 and 3 when restricted feed was practiced. The animals customarily begin to eat rapidly upon returning to their respective pens, where the complete ration was waiting in the feed bunk, and within 2 or 3 hours had eaten nearly all their daily allowance. Mean daily DM intake of complete ration $\mathrm{B}$ was $1.01 \mathrm{~kg}$ greater than that of $\mathrm{A}$ in the preliminary period and .69

'Digestible energy. 
TABLE 2.-Mean daily intakes per treatment of complete rations, basal concentrates, dry matter and dry matter relative to liveweight

\begin{tabular}{|c|c|c|c|c|c|c|}
\hline \multirow[b]{2}{*}{ Criterion } & & \multirow{2}{*}{$\begin{array}{l}\text { Preliminary } \\
\text { Period }\end{array}$} & \multicolumn{4}{|c|}{ Comparison period } \\
\hline & & & 1 & 2 & 3 & $1-3$ \\
\hline \multicolumn{7}{|c|}{ Treatment $A$} \\
\hline Complete ration & $(\mathrm{kg})$ & 16.16 & 20.29 & 17.20 & 17.50 & 18.32 \\
\hline Basal concentrates & $(\mathrm{kg})$ & 9.70 & 12.27 & 10.32 & 10.50 & 10.99 \\
\hline Dry matter' & $(\mathrm{kg})$ & 14.33 & 18.00 & 15.10 & 15.54 & 16.21 \\
\hline Dry matter/liveweight & (\%) & 2.62 & 3.23 & 2.78 & 2.84 & 2.96 \\
\hline Liveweight & $(\mathrm{kg})$ & 547 & 557 & 543 & 547 & 548 \\
\hline \multicolumn{7}{|c|}{ Trealment $B$} \\
\hline Complete ration & $(\mathrm{kg})$ & 17.24 & 21.00 & 17.09 & 17.00 & 18.53 \\
\hline Basal concentrate & $(\mathrm{kg})$ & 10.34 & 12.60 & 10.25 & 10.20 & 11.12 \\
\hline Dry matter' & $(\mathrm{kg})$ & 15.34 & 18.69 & 15.04 & 15.11 & 16.43 \\
\hline Dry matter/liveweight & (\%) & 2.88 & 3.41 & 2.69 & 2.56 & 2.98 \\
\hline Liveweight & $(\mathrm{kg})$ & 533 & 548 & 560 & 591 & 552 \\
\hline \multicolumn{7}{|c|}{ Treatment $C$} \\
\hline Basal concentrates & $(\mathrm{kg})$ & 6.68 & 8.49 & 5.97 & 5.92 & 6.79 \\
\hline Dry matter ${ }^{2}$ & & 5.93 & 7.54 & 5.23 & 5.25 & 6.01 \\
\hline Dry matter/liveweight & $(\%)$ & 1.09 & 1.37 & 0.93 & 0.97 & 1.09 \\
\hline Liveweight & (kg) & 546 & 552 & 560 & 542 & 550 \\
\hline
\end{tabular}

TTotal.

2Supplemental.

$\mathrm{kg}$ greater in comparison period 1 , whereas A slightly exceeded $\mathrm{B}$ in periods 2 and 3 (table 2 ). The small differences of .22 $\mathrm{kg}$ across the three comparison periods was in favor of B. Daily DM intakes from the complete rations relative to $\mathrm{LW}$ are expressed in a form that facilitates comparison with other experiments (table 2). Traditionally a daily DM intake equal to $3.2 \%$ of $\mathrm{LW}$ has been considered normal ad libitum consumption with common dairy ration in North America (5). Over the full comparison phase, A and B showed nearly the same relative DM intake, just short of $3 \%$ of LW daily.

Daily intakes of the concentrate portion of both complete rations exceeded $12 \mathrm{~kg}$ in comparison period 1 and remained above $10 \mathrm{~kg}$ during the final 2 periods (table 2). Daily concentrate consumption by the control cows was about 4.0 to $4.5 \mathrm{~kg}$ lower than said levels. The treatment $\mathrm{C}$ mean of $6.79 \mathrm{~kg}$ was $62 \%$ and $61 \%$ of those of $A(10.99 \mathrm{~kg})$ and B (11.12 $\mathrm{kg}$ ), respectively. Mean daily consumption of supplemental DM relative to $\mathrm{LW}$ by the control cows reached $1.37 \%$ in period 1 (table 2 ). However, after adjustment of daily concentrate assignments for declining milk yield 
at the start of period 2, concentrate DMI was slightly less than $1 \%$ of $\mathrm{LW}$ thereafter. These figures constitute moderate levels of supplementation of the grazing animals. Hay consumed as part of the complete rations exceeded $8 \mathrm{~kg}$ daily during the 1st comparison period and subsequently remained in the range of 6.8 to $7.0 \mathrm{~kg}$. In view of the differences in concentrate intake, pasture herbage consumption on an equivalent $D M$ basis by the control cows could have been appreciably higher than hay consumption from the complete rations. However, part of the differences in nutrient intake from concentrates could also have been compensated for by higher quality of the herbage.

Mean milk yield during 8 preliminary days showed a maximum difference between treatments of $1.42 \mathrm{~kg}$ daily $(18.73 \mathrm{vs} .17 .31 \mathrm{~kg}$ ), with A highest and B lowest (table 3). Pens 2 and 3 of A produced 18.22 and $19.23 \mathrm{~kg}$ vs. 18.59 and $15.44 \mathrm{~kg}$ from pens 1 and 4 of $\mathrm{B}$, respectively; the 5 cows of C ranged from 15.98 to $19.70 \mathrm{~kg}$. None of the experimental animals produced less than $15 \mathrm{~kg}$ nor more than $22 \mathrm{~kg}$ daily. Treatment means of milk yield increased slightly in comparison period 1 relative to the previous period, more so in A (table 3); one of the replicates of both $A$ and $B$ (pens 2 and 4 ) increased and the other (pens 1 and 3 ) decreased; the difference between replicates of $\mathrm{A}$ involved a change of ranking and became wider than previously ( $20.37 \mathrm{vs.} 17.93 \mathrm{~kg}$ ), while the difference between replicates of B narrowed (18.17 vs. $16.12 \mathrm{~kg}$ ). Among the control

TABLE 3.-Mean daily yields per treatment of milk and $4 \%$ fat-corrected milk (FCM), percentage milk fat, and FCM yield per unit of concentrates dry matter intake (DMI)

\begin{tabular}{|c|c|c|c|c|c|c|}
\hline \multirow[b]{2}{*}{ Criterion } & & \multirow{2}{*}{$\begin{array}{l}\text { Preliminary } \\
\text { period }\end{array}$} & \multicolumn{4}{|c|}{ Comparison period } \\
\hline & & & 1 & 2 & 3 & $1-3$ \\
\hline \multicolumn{7}{|c|}{ Treatment $A$} \\
\hline Milk yield & $(\mathrm{kg})$ & 18.73 & 19.15 & 18.06 & 15.86 & 17.69 \\
\hline FCM yield & $(\mathrm{kg})$ & 13.90 & 15.96 & 15.73 & 13.41 & 15.03 \\
\hline Milk fat content & $(\%)$ & 2.28 & 2.89 & 3.14 & 2.97 & 3.00 \\
\hline \multirow[t]{2}{*}{ FCM/DMI } & & 1.62 & 1.48 & 1.74 & 1.44 & 1.55 \\
\hline & & Treatment $B$ & & & & \\
\hline Milk yield & $(\mathrm{kg})$ & 17.31 & 17.35 & 16.84 & 15.37 & 16.52 \\
\hline FCM yield & $(\mathrm{kg})$ & 13.08 & 14.78 & 13.86 & 12.63 & 13.72 \\
\hline Milk fat content & $(\%)$ & 2.46 & 2.96 & 2.82 & 2.81 & 2.87 \\
\hline \multirow[t]{2}{*}{ FCM/DMI } & & 1.42 & 1.32 & 1.54 & 1.36 & 1.39 \\
\hline & & Treatment $C$ & & & & \\
\hline Milk yield & $(\mathrm{kg})$ & 18.11 & 18.23 & 16.12 & 13.60 & 15.95 \\
\hline FCM yield & $(\mathrm{kg})$ & 15.28 & 15.25 & 15.16 & 11.82 & 14.04 \\
\hline Milk fat content & $(\%)$ & 2.96 & 2.91 & 3.56 & 3.13 & 3.19 \\
\hline FCM/DMI & & 2.58 & 2.02 & 2.90 & 2.25 & 2.34 \\
\hline
\end{tabular}


cows, two increased their production and three decreased in period 1 , whereas the spread from the low to the high cow widened (15.54 to 20.32 $\mathrm{kg}$ ). In general there were only small differences among treatments in milk yield response during the first 36 days of experimentation, which constituted the most sensitive interval of earlier lactation.

The first day of period 2 a Brown Swiss cow in pen 1 went off feed. Later during the night she developed acute bloat. This condition was not noticed until nearly dawn, by which time immediate emergency measures were needed, but these were not administered in time and the animal died. Post-mortem examination revealed very compact reticulorumen contents, but it cannot be stated with certainty whether this compaction caused the bloating or whether it resulted from rumen stasis that set in after the digestive disturbance started.

The 5 surviving animals of treatment $B$ had yielded 17.31 and 17.35 $\mathrm{kg}$ of milk daily in the preliminary and first comparison periods, respectively (table 3 ). Subsequently they produced 16.84 and $15.37 \mathrm{~kg}$ in periods 2 and 3 . This rate of decline in production with time was very similar to that observed in A, whereas a steeper decline occurred in C. Milk yields during 84 days of the full comparison phase varied as follows: pens 2 and 3 of A, 18.79 and $16.59 \mathrm{~kg}$; pens 1 and 4 of B, 17.81 and $15.47 \mathrm{~kg}$; control cows, $13.85 \mathrm{~kg}$ lowest to $17.23 \mathrm{~kg}$ highest; means of A, B and C, 17.69, 16.52 and $15.95 \mathrm{~kg}$ daily. The latter figures, which did not differ significantly at $\mathrm{P}=.05$, represent 94,95 and $88 \%$ of the respective preliminary period yields. Thus, there was a trend toward slightly greater lactational persistency with the complete rations than with conventional management.

Mean milk fat percentages of all 3 treatments were inferior to the legal minimum of $3 \%$ for whole milk marketed in Puerto Rico at the preliminary sampling (table 3 ). Values lower than $2 \%$ were observed for the mean of pen $3(1.93 \%)$, and for a control cow (1.50\%). By contrast, the other 4 controls showed milk fat contents of $3 \%$ or more. All the treatments resulted in marginal fat concentrations again in comparison period 1 , but none of the replications of $\mathrm{A}$ or $\mathrm{B}$ had means lower than $2.82 \%$, and the formerly low cow of $\mathrm{C}$ increased to $2.9 \%$. The control cows produced milk of adequate fat content in periods 2 and 3 and over the full comparison phase. Mean fat percentage of A increased to a satisfactory level (3.14) in period 2 , but decreased again in period 3 (2.97), leading to a value of exactly 3 for the full comparison phase. Milk fat content of $B$ remained marginal until the end of the experiment, although pen 4 averaged $3.01 \%$ during the comparison phase. The means of 3.00 , 2.87 and $3.19 \%$ of $\mathrm{A}, \mathrm{B}$ and $\mathrm{C}$ (table 3 ) did not differ significantly given the few observations involved, but the logical trend was observed toward higher milk fat concentration with grazing and moderate levels of concen- 
trate feeding in $\mathrm{C}$; followed by that obtained with complete ration $\mathrm{A}$, containing coarsely chopped hay; and finally that of $\mathrm{B}$, based on hay ground to medium fineness.

Sutton (9) in his review concluded that milk fat content is fairly stable until the proportion of forage to concentrates in the ration DM falls to about $50 \%$. Below this ratio fat percentage usually declines depending upon many other factors. The generally recommended practial guide is that a minimum of $1 / 3$ of the ration DM should be long hay or its equivalent as a roughage source (4). Forage particle size is one important measure of roughage value. In one study $6.4 \mathrm{~mm}$ was found to be the minimum mean length of alfalfa hay particles for maintaining normal milk fat content (11). It should be emphasized that mean particle length is not the same as the diameter of the holes of the screen through which a forage is ground, but is, in fact, a rather complex mathematical concept (10). Sufficient fiber of proper physical form is also necessary in the ration for maximum feed intake and normal rumen function (4). The occurrence of a case of fatal bloat in treatment $B$ points to the possible risk of feeding a ration devoid of long forage particles at high levels to dairy cows.

Yield of $\mathrm{FCM}$ was highest for treatment $\mathrm{C}$ during the preliminary period, but throughout the comparison phase A maintained the lead in this productive criterion; $\mathrm{B}$ was lower than the control during comparison periods 1 and 2, but not 3. Mean daily FCM yields of $\mathrm{A}, \mathrm{B}$ and $\mathrm{C}$ over the full comparison phase, of $15.03,13.72$ and $14.04 \mathrm{~kg}$. did not differ at $\mathrm{P}=.05$, nor did corresponding daily milk fat yields of $.530, .475$ and .511 $\mathrm{kg}$ differ significantly.

Mean LW per treatment upon completion of the preliminary period was nearly alike for $\mathrm{A}$ and $\mathrm{C}$ and about $12 \mathrm{~kg}$ lower for B (table 2). Thereafter, means of $\mathrm{A}$ and $\mathrm{C}$ treatments showed erratic fluctuations with no clear trend, whereas in B there was a consistent increase in LW, though not enough to result in variation among treatments at $\mathrm{P}=.05$. Nevertheless, this observation is consistent with the fact that the cows of B had the highest feed intake and lowest FCM yield, which presumably left them with a larger surplus of nutrients available for body reserves.

FCM production per unit of DM consumed from the complete rations was one of the measures of gross feed efficiency considered. Although a ratio of 1.0 might be taken as a reasonable goal with this type of ration, a ratio this high was achieved only by $\mathrm{A}$ in period 2 (1.04). Higher milk yield than that of the present study and a more stable milk fat percentage, not lower than 3.0 , would facilitate consistent achievement of the 1.0 ratio or better. However, the ratio of .93 for A over the full comparison phase can be considered relatively favorable, whereas that of .84 for $B$ indicates the need for modification of this ration. The conversion ratios applicable to all three treatments presented in table 3 are partial efficien- 
cies, taking into account only DM intake from concentrates. A partial ratio of at least 2.5 should be attainable with careful supplementation under good grazing conditions, such as those of the present experiment. This level of efficiency was achieved with the control treatment in the preliminary period and amply exceeded in comparison period 2, whereas in period 1 higher intake of concentrates, and in period 3 lower milk fat content were factors adversely affecting FCM output per unit of supplemental DM. At least the ratio of 2.34 obtained with treatment $\mathrm{C}$ over the full comparison phase (table 3) represents better efficiency in the use of concentrates than that which usually prevails in local commercial herds. A saving of concentates was realized in the control treatment relative to the complete rations (table 3 ) which illustrates one of the well-known advantages of high-quality grazed forage.

With regard to general health of the animals, those of $\mathrm{C}$ were free of problems throughout the experiment. Among those of A, one cow had clinical mastitis briefly and three others required intrauterine infusions to combat metritis; one of the latter also exhibited abnormal estrous cycles and frequent heat periods. One cow of $\mathrm{B}$ had clinical mastitis that responded to therapy, whereas the case of another, affecting 2 quarters, was a chronic infection that intensified periodically in spite of repeated intramammary infusions of antibiotics. This animal also showed a purulent vaginal discharge on one occasion and required several intrauterine infusions. The cow that died in period 2 had suffered clinical mastitis in one quarter and weakness (resembling symptom of hypocalcemia) for 2 days before developing fatal bloat.

The management routine with the complete rations seemed to aid in the prevention of both hyperthermia and symptoms of hampered motility, such as stiffness and sore hooves, often experienced by animals in complete confinement. Ingestive activity took place during late afternoon and evening, whereas during the hours of greatest ambient heat the cows rested, confortably shaded and with relief for their hooves from the concrete floor of the pens. Under those conditions it was unusual to see exaggerated panting or other signs of distress commonly seen in cows fed intensively during midday. According to McDowell (3), cattle increase their respiration rate progressively with increasing air temperature, the most prominent rise occurring above $29^{\circ} \mathrm{C}$. Mean daily maximum air temperatures recorded during the 4 months of this experiment (March to June) were $30.7,30.9,32.1$ and $32.8^{\circ} \mathrm{C}$, clearly exceeding the level at which panting would be expected even in the absence of the extra heat load associated with feed intake. The cows of A and B were often observed lying down and ruminating during their stay in the rest area.

It is concluded that complete rations containing $60 \%$ of highly digestible concentrates and $40 \%$ of moderate-quality gramineous hay, are con- 
sumed at high levels and could constitute an attractive alternative for use with dairy cows of adequate productive potential. The complete ration with coarsely chopped hay $(A)$ proved to be more suitable than that containing hay ground to a smaller particle size (B), in terms of milk fat content and, presumably, maintenance of normal conditions in the digestive tract. Possible improvements in this system of feeding could include more careful selection of the hay used, variations in the forage to concentrate ratio or in the feeding frequency, and adjustment of feed allotments to the energy balance of the cows rather than to their milk production. The conventional feeding system resulted in nearly as high milk yield as that obtained with the complete rations but with less investment in concentrate feeds. This conventional system continues to be advantageous for use on dairy farms with a sufficient area of improved pasture to permit limiting the stocking rate, to 2.5 cows/ha. At unit costs, for ingredients and the mixing operation, of about $16 \varnothing$ and $20 \notin$ per $\mathrm{kg}$ of the complete rations and of basal concentrates, respectively, total daily feed costs per cow can be estimated at roughly $\$ 2.95$ for treatments with complete rations, as opposed to supplemental concentrate costs of $\$ 1.36$ for the control, over the full comparison period. With milk being sold at $50 \%$ per $\mathrm{kg}$, daily income therefrom averaged $\$ 8.55$ for the two complete rations vs. $\$ 7.98$ for the control; and income above feed costs is estimated at $\$ 5.60$ for the complete rations. Thus, unless pasture costs exceeded $\$ 1.02$ daily, and they should not, the grazing system was a better economic alternative at the present level of production. The complete ration method would be more competitive economically when used with cows of higher productive potential. Furthermore, it constitutes an alternative for farms where grazing under the present conditions cannot be practiced.

\section{LITERATURE CITED}

1. AOAC, 1980. Official Methods of Analysis. 13th ed. Association of Official Analytical Chemists. Washington, D.C.

2. Coppock, C. D., D. L. Bath and B. Harris, Jr., 1981. From feeding to feeding systems. J. Dairy Sci. 64: 1230-49.

3. McDowell, R. E., 1972. Improvement of Livestock Production in Warm Climates. W. H. Freeman \& Co., San Francisco.

4. National Research Council, 1988. Nutrient Requirements of Dairy Cattle. 6th ed., update 1989, National Academy Press, Washington, D.C.

5. National Research Council, 1987. Predicting Feed Intake of Food-producing Animals. National Academy Press, Washington, D.C.

6. National Research Council, 1978. Nutrient Requirements of Dairy Cattle. 5th ed., National Adademy of Sciences, Washington, D.C.

7. Randel, P. F., A. Ramirez, R. Carrero and X. Valencia, 1972. Alkali-treated and raw sugarcane bagasse as roughages in complete rations for lactating cows. $J$. Dairy Sci. 55: $1492-5$. 